\title{
TEKNIK PEMERIKSAAN ISI USUS IKAN PATIN DARI SUNGAI MUSI SUMATERA SELATAN
}

\author{
Burnawi $^{*}$ \\ ${ }^{*}$ Teknisi Litkayasa pada Balai Riset Perikanan Perairan Umum, Palembang
}

\section{PENDAHULUAN}

Ikan patin merupakan jenis ikan ekonomis penting yang sangat populer di Pulau Sumatera dan Kalimantan. Jenis ikan ini hidup dan berkembang biak secara alami di perairan umum, terutama di sungai-sungai besar seperti Sungai Musi, Sungai Batanghari, Sungai Barito, dan Sungai Kapuas.

Studi aspek biologi ikan tentang isi saluran pecernaan makanannya sangat berguna untuk memahami kebiasaan makanannya. Oleh karena itu studi tersebut berguna untuk pengelolaan sumber daya ikan patin di perairan Sungai Musi.

Adapun tujuan penulisan makalah adalah hendak menguraikan teknik pemeriksaan isi usus ikan patin yang diperoleh dari Sungai Musi Sumatera Selatan.

\section{POKOK BAHASAN}

\section{Bahan}

1. Air

2. Larutan formalin $10 \%$

3. Saluran pencernaan ikan patin

4. Karet gelang

5. Kantong plastik

6. Kertas kalkir

\section{Alat}

1. Dessecting set

2. Cawan petri

3. Timbangan dengan ketelitian $0,01 \mathrm{~g}$

4. Loupe/mikroskop

5. Baskom dan ember

6. Kotak plastik (cool box)

7. Pensil 2 B.

\section{CARA KERJA}

Pengamatan isi saluran pencernaan dilakukan berdasarkan indek bagian terbesar yang dikembangkan oleh Lager K.F. (1991) dalam (Arifin et al., 1996).

Cara memeriksa dan mengamati usus ikan patin ada beberapa tahapan:

\section{Pengawetan usus}

Ikan patin diletakkan di atas talenan, kemudian dibedah bagian perutnya mulai dari pangkal sirip dada hingga ke lubang anus. Pembedahan ini dilakukan memakai gunting dan pisau bedah. Ketika membedah perut ikan tersebut harus dilakukan secara hati-hati supaya tidak melukai usus ikan sehingga isinya tidak keluar atau tercecer.

Usus ikan dipotong mulai dari bagian mulut sampai ke anus, kemudian dimasukkan ke dalam kantong plastik dan diberi cairan formalin $10 \%$, sehingga seluruh usus ikan terendam dalam cairan formalin tersebut. Sebelum kantong tersebut ditutup dan diikat memakai karet gelang, diberi identitas sampel yang ditulis kalkir dengan pensil 2 B mengenai: nama ikan, ukuran, tempat, dan tanggal pengambilan sampel. Kemudian kantong plastik disimpan dalam box penyimpanan (cool box).

\section{Pemeriksaan isi usus}

Usus ikan dikeluarkan dari kantong plastik dan dimasukkan ke dalam baskom, selanjutnya dibilas memakai air sebanyak 3 kali sampai bau formalinnya hilang. Usus ikan dibedah atau dipotong memakai pisau bedah secara memanjang. Semua isi usus dikeluarkan dan ditampung dalam cawan petri, dibiarkan atau 
Tabel 1. Komposisi pakan alami ikan patin di Sungai Musi

\begin{tabular}{|c|c|c|}
\hline No. & Nama Bahan & Prosentase $(\%)$ \\
\hline 1. & Buah (pedado, jambu air) & 40,40 \\
\hline 2. & Ikan & 3,54 \\
\hline 3. & Daging dan tulang (hewan) & 1,43 \\
\hline 4. & Molusca & 0,14 \\
\hline 5. & Crustacea & 0,56 \\
\hline 6. & Umbi-umbian & 0,70 \\
\hline 7. & Insekta & 0,01 \\
\hline 8. & Detritus & 11,96 \\
\hline \multirow[t]{2}{*}{9.} & Tidak teridentifikasi & 36,16 \\
\hline & Jumlah & 100,00 \\
\hline
\end{tabular}

dikering-anginkan selama \pm 10 menit. Setelah pengeringan selesai semua isi usus ditimbang untuk menentukan berat pakan alami yang ada dalam usus ikan setiap ekornya.

Tahapan kerja berikutnya adalah memilah dan mengelompokkan jenis-jenis pakan secara kasat mata. Bila isi perut tersebut tidak teridentifikasi maka diidentifikasi memakai mikroskop (binokuler). Jenis-jenis makanan yang ditemukan selanjutnya dihitung berdasarkan persentase dari isi usus yang diperiksa.

\section{HASIL PEMERIKSAAN}

Hasil pemeriksaan isi perut ikan patin ditemukan berbagai jenis bahan makanan, yaitu: buah-buahan, ikan, hewan, molusca, crustacea, umbi-umbian, insekta, detritus, dan lain sebagainya. Ikan patin termasuk ikan omnivora, lebih dominan memakan buah-buahan dan ditritus (Tabel 1).

\section{KESIMPULAN}

1. Teknik pemeriksaan usus ikan patin memakai indek bagian terbesar sebaiknya dimodifikasi memakai metode lainnya karena banyak jenisjenis pakan yang tidak teridentifikasi.

2. Makanan ikan patin di Sungai Musi adalah buah-buahan dan detritus.

\section{DAFTAR PUSTAKA}

Arifin, Z., A. Karim Gaffar, \& Susilo Adjie. 1996. Studi biologi ikan langka DAS Musi. Laporan Intern Loka Penelitian Perikanan Air Tawar Palembang.

\section{UCAPAN TERIMA KASIH}

Penulis menghaturkan terima kasih sebesarbesarnya kepada Bapak Dr. Ir. Mas Tri Djoko Sunarno, M.S., Drs. Susilo Adjie, dan Drs. Dadiek Prasetyo yang telah memberi saran dan koreksinya, dan dewan redaksi serta pengetik naskah sehingga terlaksananya tulisan ini. 